\title{
Representing A Sustainable World - A Typology Approach
}

\author{
Don Clifton \\ University of South Australia, City West Campus, North Terrace, Adelaide, South Australia \\ Tel: 61-8-8463-0850Ｅ-mail: doncmail@bigpond.net.au
}

\begin{abstract}
This paper presents, as a 'sustainable world typology', the findings of a current research project that is concerned with what it means for there to be a sustainable world and how humanity might go about achieving this. The typology is framed around key sustainable world dimensions and displays, for each of these dimensions, how Reformist and Transformational approaches are conceived in terms of giving meaning to the concept of a sustainable world. Key themes evident in the typology are discussed namely: (a) the primary sustainable world goal of flourishing life, (b) the anthropocentrism-ecocentrism divide, (c) approaches to human interests satisfaction, and (d) optimisation vs resilience living. The paper notes the mere descriptive nature of the typology and concludes with some thoughts on ways in which the typology might be critiqued to identify which approach, Reformist or Transformational, is more likely to see the primary sustainable world goal achieved.
\end{abstract}

Keywords: Sustainability, Sustainable world, Reformist, Transformational, Typology

\section{Introduction}

\subsection{Purpose of this paper}

This paper reports on a component of a current research project that is concerned with what it means for humans to live sustainably on the Earth, that is, for there to be a sustainable world, and how humanity might go about achieving this. The full project considers three key questions namely: (a) what does it mean for there to be a sustainable world?, (b) what approach to a sustainable world is being pursued by a specific Australian state government?, and (c) what are the implications of this government's sustainable world approach in respect of its contribution to, or detraction from, a global sustainable world goal? This paper presents the findings from research undertaken to answer the first of these three questions.

\subsection{Typology approach}

Dobson (1996), in considering ways in which the meaning of complex pluralistic concepts such as that of a sustainable world can be presented, proposes a typology approach as preferable to alternates such as definitional or discursive methods. The approach taken in this paper follows Dobson's advice and presents a summation of different perspectives of what it means for there to be a sustainable world in the form of a 'sustainable world typology' (SWT), shown as Figure 1.

A number of existing typologies that are oriented towards sustainable world issues are evident in the literature and these can be categorised into three main forms. First, sustainable world dimension (SW Dimension) typologies are those that focus on what are seen as key dimensions (or principles) that collectively present a picture of what is means for there to be a sustainable world and how this might be achieved. These SW Dimensions typically include items such as how natural resources are to be used, how human interests are to be satisfied, intergenerational equity obligations, and so on. Typologies of this form display different approaches to these dimensions, with these approaches often collapsed into 2, or at the most 4, representative categories. Examples of this form of typology include those of Gladwin, Kennelly and Krause (1995), Dobson (1996), Diesendorf (1997) and Naess (2003)). Second, world-view typologies are those that focus on presenting key aspects of different world-views that have a sustainability orientation, such as ecological modernisation, ecofeminism, deep ecology, and so on. Examples of this form of typology include those of McManus (1996) and McGregor (2004). Third are prose-based typologies that present descriptions of alternate sustainable world approaches in paragraph rather than tabular form (Williams and Millington (2004) is an example). As this paper is concerned with giving meaning to the sustainable world concept, as opposed to exploring word-views for their own sake, the SW Dimensions typology approach has been adopted.

\subsection{Contribution to the literature}

The SWT, presented as Figure 1, adds to the literature by filling a number of gaps evident in existing typologies by:

Expanding the list of SW Dimensions that are incorporated in existing typologies.

Adding to the content description of all SW Dimensions shown.

Adding to each of the SW Dimensions a description of what is identified in the literature as being inconsistent with either of the two sustainable world formulations presented, namely the Reformist and the Transformational formulations. 
Identifying, for each SW Dimension, which approach to a sustainable world is presented in the literature as being dominant in the political and business sector domains.

Identifying for each SW Dimension, which approach best represents the consequences of current human behaviour.

\subsection{Typology - moving beyond a mere descriptive}

Although typologies are useful for giving meaning to complex pluralistic constructs such as that of a sustainable world, they remain merely descriptive. For the SWT, different views on what it means for there to be a sustainable world might be interesting to know, but on its own, this is of limited use. Of greater interest is gaining insight into which sustainable world approach is more likely to see humanity progress in an orderly manner to a sustainable world outcome. Although beyond the scope of this paper to undertake such an analysis, some preliminary comments on further research to progress such a critique of the SWT, that also forms part of the broader research project on which this paper is based, are presented as concluding comments.

\subsection{Paper layout}

The paper proceeds as follows. First, the methodology used in developing the SWT is presented, including a description of the processes that were followed and the questions that were answered to help drive the analysis work and SWT construction. The findings of the research are then presented in the form of the SWT and a discussion of the main themes that are evident in it. The paper then concludes by considering two approaches for critiquing the SWT to help assess which of the two sustainable world formulations it presents is more likely to see the primary goal of a sustainable world achieved.

\section{Methodology}

\subsection{Initial typology review}

The SWT, shown as Figure 1, was constructed from a review of the sustainability literature, beginning with a review of existing sustainable world oriented typologies, including those of Gladwin, Kennelly and Krause (1995), Dobson (1996), McManus (1996), Diesendorf (1997), Naess (2003), McGregor (2004) and Williams and Millington (2004). From these typologies, an initial set of SW Dimensions, that is, dimensions the typology authors considered to be key aspects of what it means for there to be a sustainable world and how this might be achieved, were identified.

\subsection{Reformist and Transformational approaches}

Existing typologies were also used to consider how different perspectives towards each of the SW Dimensions might be categorised. The approach taken in the SWT has followed the Reformist-Transformational categorisation, providing consistency with themes displayed in the established literature and as used in a number of existing typologies. The Reformist approach is one that focuses on progressing the achievement of a sustainable world by reforming the current dominant socio-economic system through changes at the margin to make this system more environmentally responsible and socially just (green-and-just) (Cato 2009; Fox 2003; Madore 2006; Williams and Millington 2004), that is, the "promulgation of reforms that do not challenge the basis of our societies but that may lead to changes in emphasis at the margins" (Handmer and Dovers 1996, p. 499). Other tag names used for the Reformist view include 'weaker sustainability' (Kallio, Nordberg, and Ahonen 2007; Williams and Millington 2004), 'reform environmentalism' or 'reform ecology' (Fox 1995; Light 2000), and 'shallow ecology' (Fox 1995; Naess 2003). The Transformational approach however, claims that progressing to, and the maintaining of, a sustainable world requires fundamental and transformational socio-economic system change (Cato 2009; Williams and Millington 2004), and where society has a "preparedness to adopt new basic operating assumptions and institutional structures (Handmer and Dovers 1996, p. 501). Other tag names used for the Transformational view include 'stronger sustainability' (Kallio, Nordberg, and Ahonen 2007; Williams and Millington 2004), 'new environmental paradigm' (Bell 2009), 'ecological social paradigm' (Bell 2009), and 'deep ecology' (Fox 1995; Naess 2003).

Next, key sustainability terminologies were identified from the literature, they being 'sustainability', 'sustainable development', 'environmentally/ecologically sustainable-development', 'social sustainability', 'economic sustainability' and 'environmental/ecological sustainability/sustainable-development'. A review of the literature was then undertaken to answer three questions in respect of each of these terminologies namely: (a) what is sought to be sustained?, (b) what is needed to see the things in (a) achieved?, and (c) what outcomes flow if the things in (a) are in fact achieved? The results of this analysis produced a broad and often conflicting set of answers for all three questions which provided a base of data to progress the SWT construction.

\subsection{Questions addressed from the literature review}

From there, using data from the review of existing typologies, from the sustainability terminology analysis, and those derived from a broader literature review, the answer to one key question was initially sought namely 'what is the primary goal of a sustainable world - what is it that is to be sustained above all else?' The answer was found to be 'the flourishing of life on Earth over an indefinite time frame' (see SWT items 1.1 and 2.1). This focus on flourishing life is evident implicitly and explicitly in the literature, captured in general sustainability 
descriptions such as those in the 1969 IUCN mandate (Adams 2006) and the 1987 Brundtland Report (WCED 1987), through to other descriptions specifically referring to 'flourishing life' (ECC 2000; Engel 2004; Naess 2003).

From this starting point, a literature review, comprising approximately 400 articles and books (note 1), proceeded framed around answering these questions:

If the primary sustainable world goal is the flourishing of life, then what forms of life matter and what does it mean for this life to flourish?

How is this flourishing to be achieved?

Who is responsible for the unsustainable state of human behaviour, and who is responsible for remedying it?

What other SW Dimensions in terms of social values, social responsibilities and obligations, actions, outcomes, or any other matter, are evident that give meaning to the concept of a sustainable world and how it might be achieved?

How are the issues identified in the above 4 questions considered in terms of different approaches to how the concept of a sustainable world is formulated?

In relation to point (e), what is the current dominant sustainable world approach and in what way is it dominant?

What behaviours are inconsistent with any of the sustainable world formulations identified in point (e)?

What is the current dominant human behaviour in respect of each of the SW Dimensions?

\subsection{Data collection and analysis}

The literature review, data collection, and data analysis processes were conducted in parallel to the point of saturation. In this context, saturation was the point where additional literature sources, while possibly continuing to add to the fine detail, failed to add anything material to the core answers to each of the questions under consideration. The end result of this progressive review-collection-analysis process was: (a) the set of SW Dimensions as set out in the SWT, (b) the allocation of perspectives for each SW Dimension into the Reformist and Transformational categories (although for some SW Dimensions, more than two positions are presented), (c) for each SW Dimension, the inclusion of a statement of what is inconsistent with either a Reformist or Transformational approach, and (d) for each SW Dimension, identification of the current dominant sustainable world approach and current dominant human behaviour.

\subsection{SWT limitations}

The SW Dimensions shown in the SWT do not necessarily cover every possible SW Dimension that might be extracted from the literature, and those that are shown could be collapsed or expanded in different ways. The categorisation into Reformist and Transformational views also masks the variance of thought that exists within these two broad classifications, including sustainable world approaches that might sit at the extremes. Further, a typology is, by its nature, a summary representation and as such is limited in depth of content (Dobson 1996). Nonetheless, the SWT offers a useful summation of the main streams of sustainable world thought that are evident in the literature.

\section{$<$ Insert figure 1 here $>$}

\section{Findings}

\subsection{The SWT-major themes}

The SWT shows that there is little agreement between the Reformist and Transformational camps. What is common to both can be summarised as follows:

'A sustainable world has to do with the flourishing of life on Earth, incorporating both human and ecological wellbeing, over an indefinite time frame. This wellbeing is grounded in principles of intra-generational and inter-generational justice, and in the maintaining of biological and human-cultural diversity. Current sustainable world problems are human caused and only humans can take the needed action to remedy this'.

Beyond this general statement, and consistent with claims in the literature of the contested nature of the sustainable world concept (McManus 1996; Porritt 2005; Wissenburg 2001), there is little common ground between Reformist and Transformational formulations. Answers to questions such as which life forms matter?, how is wellbeing to be achieved?, what does it mean to act in a just way within and between generations?, what does it mean to maintain diversity? - and so the list goes on - are subject to significant disagreement. Space limitations in this paper prohibit a detailed walk through of answers to these and other questions by way of a line-by-line SWT discussion. Instead, the remainder of this section considers some of the main themes evident in the SWT, which will hopefully serve as a useful guide to a more detailed reading of the SWT itself (note 2).

3.1.1 Flourishing of life

The first of these main themes has to do with a sustainable world being concerned with the flourishing of life (SWT item 1.1), not its mere subsistence existence. In this respect, and paraphrasing Leopold's claim that "[a] thing is right when it tends to preserve the integrity, stability, and beauty of the biotic community. It is wrong 
when it tends otherwise" (Leopold 2003), a general claim can be made that 'a thing is supportive of a sustainable world when it contributes to the flourishing of life, and not supportive of a sustainable world when it tends otherwise'.

Although what it means for life to flourish is left somewhat vague in the literature, in the human domain it is linked to a range of ideas including that of a 'good life' (Barry 2003; Daly and Farley 2004), having meaning and value in life (Naess 1988; Taylor 1989), living healthy and productive lives (UN 1992b), having a "joyful fulfilled human existence" (Cato 2009, p. 172), and for human culture to continue to develop (Gladwin, Kennelly, and Krause 1995). In the non-human realm it is linked to ideas framed around general concepts of the wellbeing of non-human life spanning from individual organisms, to ecosystems, to the Earth as a whole, with this wellbeing being specific to what is good for the organism or system in question (for examples of such descriptions, see Taylor (1989) and Boyden (2001)). The focus on flourishing life does not mean that non-living things are without value, nor is it the case that non-living things are necessarily valued only for their instrumental use to humans (see the anthropocentrism-ecocentrism heading (below) for more on this). In addition, one view on this living vs non-living things point is that apparent non-living things, such as mountains or rivers, are parts of living ecosystems and cannot be reduced down to non-living things in any way that is meaningful. From this perspective it makes no sense to even talk of these things in reductionist non-living terms (for an example of this view, see Naess (1989; 2003; 2005)).

Two key points to be made from this flourishing of life theme however are these. First, a world in which human life (or under the Transformational view, human and non-human life) exists in a state of mere basic survival (that is, having only 'vital needs' met - those necessary for basic physical survival) is inconsistent with both the Reformist and Transformational views. For humans, eking out a life of basic survival will not do - the minimum standard is flourishing lives.

Next, although terms such as 'interests', 'needs', and 'wants' are used inconsistently in the literature to describe what must be met to achieve this flourishing of life within the sustainable world context, in this paper their use and connections are as follows:

Fulfilment interests (SWT item 1.2) are those things that are conducive to the flourishing of something (a person, a society, an animal, a plant, an ecosystem, etc.). These are high-order things which in the human context might include physical health, a sound mind, a sense of meaning and purpose in life and so on. Fulfilment interests have some common characteristics across any one species (it is in the interests for all humans to be of good health and sound mind) and in some respects, across species boundaries (physical health is just as relevant for a human as it is for an ape or an elephant). But there are also clear species specific fulfilment interests (a healthy cheetah is a fast cheetah, which need not be the case for a human) and at least within the human domain, there are individual differences as to how a flourishing life might be lived.

Fulfilment needs (SWT item 3.1) are those things that must be satisfied in order for fulfilment interests to be met - wholesome and adequate food for physical health, strong social relationships and family bonds for psychological health, and so on.

Wants (SWT item 3.1) are those things that go beyond fulfilment needs and are 'like to haves', but are not conditional for a flourishing life to be lived. I might like to trek through the Himalayas, but I can still live a flourishing life without it. Wants are mostly seen as applicable only to humans and, although not dismissing the possibility that wants might also apply to non-human species, the limitation to humans is followed in this paper.

In the sustainable world context, fulfilment interests, fulfilment needs, and wants, come together within a justice and an anthropocentric-ecocentric setting. Looking specifically at the human realm, from a justice perspective, what matters for both the Reformist and Transformational views is that human flourishing is actually achieved it is the outcome that matters (Holbrook 2009), and this needs to be achieved for all of humanity before want satisfaction is pursued (SWT items 3.1). The allocation of resources to want satisfaction for some of humanity, whilst fulfilment needs remain unmet for others, is inconsistent with both Reformist and Transformational approaches. An ecocentric overlay as is evident in the Transformational view takes this further in that a sustainable world is not achieved whilst fulfilment needs remain unmet in both the human and non-human realms (SWT item 3.1).

So in the human realm, justice is more than simply meeting certain fulfilment needs such as an adequate income, enough food, adequate housing, the provision of health care and so on, and doing so in an equitable way. What is important is the translation of need satisfaction into a flourishing life, that is, the meeting of needs must translate into the satisfaction of fulfilment interests. In this respect, justice in a sustainable world is ultimately consequentialist based and grounded in a broad set of justice principles including equitable distribution, recognition, capabilities, and participation (note 3) (O'Neill, Holland, and Light 2008; Schlosberg 2007) (SWT item 5.2). Similar notions of this broad view of justice as also being relevant to the non-human realm are evident in some ecocentric narratives (for a discussion on this extension, see Schlosberg (2007)). 


\subsubsection{Anthropocentrism - ecocentrism}

The next major theme is the anthropocentric-ecocentric divide which has a significant impact throughout the entire SWT. This aspect of divergent views on what it means for there to be a sustainable world is well recognised in the literature however some points from the SWT are worthy of note.

First is that although the Reformist view is linked in the literature to anthropocentrism (Bell 2009; Gladwin, Kennelly, and Krause 1995; Williams and Millington 2004), this linkage is really in terms of what some authors have referred to as 'weak anthropocentrism', that is, (a) where human interests, for the most part, take precedence over non-human life, (b) where non-human life is mostly considered in terms of its instrumental value to humans, but (c) where this instrumental use is based on 'considered human preferences' (Light and Rolston 2003; Norton 2003) (SWT item 1.2). Norton (2003) defines these considered preferences as "any desire or need that a human individual would express after careful deliberation, including a judgment that the desire or need is consistent with a rationally adopted world view" (p. 164) or, as can be applied in this current setting, a rationally adopted view of a sustainable world. This idea of considered preferences is evident throughout the sustainable world literature where, for all sustainable world formulations, human actions need to be based on a broad range of human focused values, including consideration of the interests of future generations, and the cultural, spiritual, and amenity values of Nature as opposed to its mere economic value (Hargrove 2003; Light and Rolston 2003; Palmer 2003; Speth 2005; WCED 1987). In this respect, the 'strong anthropocentric' neo-classical economic approach to the satisfaction of human wants which Norton (2003) describes in terms of 'felt human preferences' that is, "any desire or need of a human individual that can at least temporarily be sated by some specifiable experience of that individual" (p. 164), is inconsistent with both a Reformist and Transformational view.

Although some authors have proposed that, in practice, application of weak anthropocentric principles will produce very similar outcomes as the ecocentric view when it comes to the protection of Nature (for a detailed review of this claim, see Minteer (2009)), this is not how the two approaches play out in the Reformist-Transformational space. The weak anthropocentric Reformist position portrays the meeting of non-human interests in ways that are fundamentally different to the ecocentric Transformational view. These differences are evident in many SW Dimensions including the priority order of interests satisfaction (SWT item 3.1), the mechanism for meeting non-human interests which extends to both 'wild' Nature and to domesticated and agricultural plants and animals (SWT item 3.2(b)), population numbers of human vs non-human species (SWT items 3.3 (a) \& (b)), how intra-generational and inter-generational justice is considered and applied (SWT item 5.2), how humans consider and address resource needs (SWT item 5.3), biodiversity maintenance (SWT item 5.6.1.), and how issues of security are considered (SWT item 5.7).

The second key point is that an ecocentric approach is concerned with the flourishing of both human and non-human life, not one to the exclusion of the other (Fox 1995; Rodman 1995). Ecocentrism does not reject the weak anthropocentric position on the instrumental use of non-human things for meeting considered human preferences - to do so would simply make human life impossible. It does however reject the weak anthropocentric view that this instrumental use by humans is the only value non-human things have. There need be no inconsistency between something, either human or non-human, having both instrumental value and value for its own sake (an example is a parent-child relationship where a parent may gain certain instrumental value from the child but the child may nonetheless be valued just for what it is). In this respect, ecocentrism adds to what weak anthropocentrism offers by way of the non-human world also having value for its own sake. In doing so, ecocentrism imposes moral obligations on humans in how the non-human world is treated that go beyond those required under a weak anthropocentric view.

Next is that although ecocentrism is linked in the literature to a Transformational view (Bell 2009; Gladwin, Kennelly, and Krause 1995; Williams and Millington 2004), some of the SW Dimensions display some apparent Transformational characteristics but do so within an anthropocentric paradigm. An example is the Human Resources Dimension (SWT item 5.3) where, although the distinction between weak-sustainability and strong-sustainability is well covered in the literature (for examples, see Daly (1990; 1996), Goodland (1995), Hediger (1999), and Common and Stagl (2005)), both of these are nonetheless economic concepts (Dovers 2005; Hediger 1999) framed within an anthropocentric world view (Wackernagel and Rees 1997). In this sense, strong-sustainability only fully embraces a Transformational approach when it is framed within an ecocentric view as some authors have attempted to do (for examples, see Diesendorf (1997), Holland (1997), and Heidiger (1999)). The SWT Security Dimension (SWT item 5.7) also shows this characteristic, in this case by way of a weak-anthropocentric overlay onto an otherwise Transformational broad-scale disarmament view. This broad-scale disarmament approach only fits comfortably within the Transformational narrative when coupled with ecocentrism (for a detailed discussion on this issue, see Clifton (2009)).

Fourth, in the literature, the flourishing of life is considered in terms of human life, and of non-human life as a collective (that is, non-human life is not dissected into listing specific species). This distinction means that for both the Reformist and Transformational views, humans are to be sustained as a species over any and all time frames, although how the species might evolve over time remains unknown. Non-human life is to be sustained over the long term as a collective, as opposed to identifying specific species that should be viewed as deserving 
to be sustained in their own right. In the shorter term however, the protection of non-human species as they exist at any point in time forms part of both the Reformist and Transformational agendas (see the SWT Biodiversity Dimension - item 5.6.1).

\subsubsection{Human interests satisfaction}

The third major theme evident in the SWT is the manner in which human interests are best satisfied.

Much of what comprises key elements of this human interests satisfaction theme are well covered in the literature, in particular, arguments concerning the merits of continued economic growth, consumption, and sufficiency living, are well rehearsed (for examples of the Reformist approach, see WCED (1987), Friedman (2006), and Hart (2007), and for examples of the Transformational view, see Douthwaite (1999), Princen (2005), and Jackson (2009)). In brief however, the Reformist view: (a) is dominated by green-and-just economic growth solutions (SWT item 3.2(a)), (b) the industrialised North helping the less/non-industrialised South to 'develop' and embrace Northern economic ideals (SWT item 4.2), and (c) where a resolution to poverty and inequitable resource allocation is dependent on strong and continuous global economic growth (SWT item 5.5). The Transformational view is substantially different and is framed around concepts of: (a) consumptive sufficiency and a focus on non-resource consumptive life satisfiers (SWT item 3.2(a)), (b) a need for the industrialised North to stop exploiting the South and to let the South pursue its own sustainable living path (SWT item 4.2), and (c) a resolution to poverty through an equitable allocation of current resources, not through the pursuit of increased resource throughput-based growth (SWT item 5.5).

In addition to the comments embodied in the SWT in relation to this issue, two further points are worthy of note. First, Transformational advocates, rather than suggesting that a sustainable world can only be achieved through humans living less rewarding lives - 'living it hard' by giving up the good things in life - propose instead that the sufficiency approach is wellbeing enhancing (McLaughlin 1995; Naess 1988; Speth 2008). For Transformational advocates, the focus on growth and consumption harms human wellbeing and is simply not able to deliver meaningful and enduring life satisfaction. Further, the Reformist growth-consumption approach is seen to undermine the wellbeing of the ecosystems on which humans depend, which ultimately comes back to harm human wellbeing.

Second, Transformational advocates do not simply claim that the pro-growth Reformist agenda is inferior to the Transformational narrative, but rather that it is fundamentally flawed, will not work, and its pursuit creates a false sense of progress towards a sustainable world that acts as a block to the more decisive and Transformational action that is needed (Daly 1996; Handmer and Dovers 1996; Jackson 2009). In this, and in other respects, the Reformist and Transformational approaches to a sustainable world are not merely positions on a continuum where differences are a matter of degree. The Reformist and Transformational views are based on fundamentally different and incommensurate paradigms beginning with the weak-anthropocentric vs ecocentric views, and permeating through the broader set of SW Dimensions (Clifton 2009).

\subsubsection{Optimisation}

The final major theme evident in the SWT that will be considered here has to do with what is sought to be optimised (getting the most out of) and maximised (getting the most of). Both the Reformist and Transformational approaches seek to maximise human wellbeing as embraced in the idea of flourishing life. It is clear from the discussion so far however, that the methods by which this maximised wellbeing is achieved are vastly different across these two streams of thought.

Although cognisant of trade-offs that might arise in pursuing the maximisation of multiple goals, a fundamental drive within the Reformist view is nonetheless focused on 'as much as can be achieved' - the highest sustained economic growth we can get (SWT item 5.5), as many people living on the Earth as can be sustained (SWT item 3.3(a)), the highest level of productivity of all resource types, human-made and natural (SWT item 5.4), and the highest level of goods and services consumption that can be achieved and sustained (SWT item 3.2(a)). The Transformational view instead sees this Reformist approach as working against the long term interests of humans (and all other species for that matter) and instead focuses its attention on socio-ecological resilience living. For the Transformational advocate, Reformism is fundamentally flawed as its obsession with optimisation and maximisation undermines the very ecological and social systems on which human wellbeing is based, and will ultimately undermine the very goal of human flourishing it seeks to achieve. This issue will be further considered later in this paper.

\subsection{Inconsistent with both Reformist and Transformational approaches}

The claims as to what is considered in the literature to be inconsistent with either the Reformist or Transformational approaches are shown in the SWT for each of the SW Dimensions. An important point concerning these claims however is that they are really only claims as to what does not even meet Reformist criteria, let alone that of the Transformational view. As alluded to above, the Reformist agenda is, in the view of Transformational advocates, mostly inconsistent with a sustainable world (for examples of this view see Farley, Erickson and Daly (2005) and Kempf (2008)). The reverse also holds true where for Reformists, much of the 
Transformational view is either or all of flawed, utopian, or simply unbelievable as a viable pathway forward (for an example of this view, see Hart (2007)).

\subsection{Current dominant sustainable world approach}

It is clear from the literature that the current dominant approach to a sustainable world is Reformism (there are numerous references supporting this view, for examples, see Handmer and Dovers (1996), Nurse (2006) and Gould and Lewis (2009)). But dominant in what way?

Firstly, looking at the dominant socio-economic system that is seen to either need reforming or transforming, the Reformist view is based on a green-and-just version of an economic growth model encompassing free trade, globalisation, a key role for multi-national corporations, a focus on technological advance, and wellbeing through increased income and consumption (SWT item 5.5). This paradigm goes under a number of tag-names in the literature including the 'technological social paradigm' or 'technocentrism' (Bell 2009; Gladwin, Kennelly, and Krause 1995), and 'liberalism' (or neo-liberalism) in the sense of liberalism being "a view of order linked to material progress, endlessly stimulated through science, technology, and corporate innovation within the lax constraints of the marketplace" (Laferriere and Stoett 2006, p. 7). It also embraces ideas consistent with human exemptionalism (Bell 2009) and modernism (Gare 2000). For Transformational advocates, it is this socio-economic system that needs more than reforming along green-and-just lines - it needs to be transformed. So in this sense, socio-economic system dominance can be seen in terms of the system that is currently dominant in the world by way of its economic and political power. Despite the claim made earlier that Reformism is based on the "promulgation of reforms that do not challenge the basis of our societies but that may lead to changes in emphasis at the margins" (Handmer and Dovers 1996, p. 499), this is not true for communities that are not yet (fully) captured within this dominant system - for them, change will be substantial.

From the view of Reformism being the current dominant approach to a sustainable world, this refers to dominance at the political level, both internationally and nationally, and in business circles (Castro 2004; Dauvergne 2008; Robinson 2004). Reformism's dominance in the international political setting is evident in the sustainable development narratives of the United Nations that made their mark with the release of the 1987 Brundtland Report (WCED 1987) and the follow-up 1992 Rio Earth Summit. This Reformist based sustainable development narrative has since become the language of sustainability at the national government level and as adopted by the business sector (Peattie 2001), as evident in narratives such as those of Agenda 21 (UN 1992a), the Network of Regional Governments for Sustainable Development (nrg4SD 2002), and the World Business Council for Sustainable Development (WBCSD 2008). So again, Reformism's dominance is grounded in its support within political and economic power centres.

\subsection{Current dominant human behaviour}

The consequences of current human behaviour are, at the global collective level, described in the literature as being for the most part inconsistent with either the Reformist or Transformational approaches, that is, humans are, as a collective, not living in ways that meet Reformist requirements let alone those of the Transformational view. This does not mean that the lifestyles, values, and behaviours of some members of society are inconsistent with a sustainable world, but when added together, the overall outcome is not.

Although some signs of Reformist consistency may be evident in certain SW Dimensions, the strong theme in the literature is that humanity is, as a collective, well placed in the 'inconsistent with both Reformist and Transformational' space.

\section{Conclusion}

The SWT presented in this paper seeks to provide some added clarity and depth to conceptualisations of what it means for there to be a sustainable world, and how the two main streams of thought evident in the literature Reformist and Transformational - consider what might be needed to achieve and maintain a sustainable world outcome. On its own however, the SWT is merely a descriptive. Of greater value is understanding which sustainable world formulation might best see the primary goal of a sustainable world - the flourishing of life on Earth - most likely to be achieved. Although beyond the scope of this paper to explore this issue in detail, the following comments are made in respect of two approaches that are being developed, as part of the broader research project referred to in this paper's introductory section, to aid in furthering this 'more-likely' understanding.

The first approach is based on the I=PAT identity (Ehrlich and Ehrlich 2008; Holdren, Daily, and Ehrlich 1995) coupled with Ecological Footprint analysis (Footprint Network 2008). I=PAT: 'I' (ecological impact - sometimes measured as Ecological Footprint) = 'P' (population) $\mathrm{x}$ 'A' (affluence) $\mathrm{x}$ ' $\mathrm{T}$ ' (technology), is a simple identity where the differences between the Reformist and Transformational approaches are clearly evident. For Reformists, reducing ' $\mathrm{I}$ ' rests mostly on ' $\mathrm{T}$ ', that is, the population and economic growth pressures that are part of the Reformist agenda are claimed to be able to be offset by ' $\mathrm{T}$ ' - changing the way we go about our production and consumption behaviours - so that 'I' falls within whatever ecological limits might apply from time to time. The Transformational view requires that 'I' is capped to be within ecological limits, and all of 'P', 'A', and 'T' are managed to ensure these ecological limits are not breached (see SWT items 3.3(a) and 5.5). The question here is 
whether the Reformist story, as the current dominant approach, is a believable one. Can a focus on ' $\mathrm{T}$ ' really do the job? Some efforts have already been made to explore this issue (for a recent example, see Jackson (2009)) however further research offers some potentially valuable insights, especially in considering what actions within the ' $\mathrm{T}$ ' category - efficiency, green consumption, increasing natural resource productivity, and so on - might be pursued and whether, in the end, these will or will not overcome 'P' and 'A' pressures.

The second, and less well researched, approach, seeks to test the Reformist and Transformational formulations in terms of their socio-ecological resilience. Although the issue of socio-ecological resilience is picked up in SWT item 5.4, its drivers (and detractors) flow throughout the entire SWT. A number of authors have pointed to the inseparable nature of the concept of socio-ecological resilience and that of a sustainable world (for examples, see Holling (1996) and Walker and Salt (2006)). The point these authors make is that unless the social and ecological systems on which the flourishing of life depends are able to continue to deliver this outcome regardless of any change or disturbance that comes their way, then we will not have a sustainable world. So testing the SWT in its entirety against socio-ecological resilience principles offers a promising set of insights as to the merits of the Reformist and Transformational sustainable world formulations.

As mentioned above, Reformism is shown in the literature to be the current dominant approach to a sustainable world. Clifton (2009), in considering why Reformism dominates, proposes three possible and non-mutually exclusive reasons for this namely: (a) Reformism is a superior approach to a sustainable world as compared to a Transformational approach (an example of this view is presented by Hart (2007)), (b) Reformism is the only viable approach within the current political and economic space (authors suggesting this may be of importance include Robinson (2004) and Barry (2007)), and (c) the sustainability narrative has been captured by the political and economically powerful elite, and modelled into the Reformist mode, to limit socio-economic system changes to the margin and protect the economic interests of the elite (authors writing in support of this view include Castro (2004) and Kempf (2008)). The type of SWT analysis proposed in this section, by way of I=PAT and socio-ecological resilience methods, can help progress understanding of point (a), as can other research work focused on the merits of the Reformist vs Transformational views (such as work testing the merits of economic growth in achieving human flourishing (see for example Daly, H and Farley (2004)), or research on the merits of ecocentric views vs anthropocentric views on caring for the environment (see for example Barr and Gilg (2006))). If however, point (c) is right - the sustainability agenda has been captured by the politically and economically powerful elite - then even if mounting evidence shows that the Transformational approach is a more likely pathway to a sustainable world, then the challenges of embracing Transformational narratives take on a whole new dimension. Hurdles in progressing to a sustainable world cannot, in this setting, be overcome by simply presenting a convincing argument. The current wrestle over the reality, or cause, or severity, of global warming, and embarking on a path of needed action, is a clear example of this dilemma (Hamilton 2007; Hoggan 2009; Pearse 2007).

A number of authors have noted that Reformism not only dominates as a sustainable world narrative, but it is also the only narrative granted legitimacy in the political and commercial realm. That is, to be heard politically or by the business community, any pathway forward for society to pursue a sustainable world must fit the Reformist view (Gould, Pellow, and Schnaiberg 2008; Handmer and Dovers 1996; McGregor 2004). But failing a collective self-extinction decision, humans have no choice but to live sustainably. An anything-is-better-than-nothing sustainable world approach will not do. We need to ensure humanity takes the road that will be most likely to succeed even if this does not sit comfortably with current dominant ideologies or power bases. Reinvigorating public discussion on a broader set of sustainable world pathways for humanity than mere adherence to Reformism is an important step forward, a cause to which this paper hopefully makes a contribution .

\section{References}

Adams, W.M. (2006). "The Future of Sustainability: Re-thinking Environment and Development in the Twenty-first Century." The World Conservation Union.

Barr, S. and A. Gilg. (2006). "Sustainable lifestyles: Framing environmental action in and around the home." Geoforum 37:906-920.

Barry, B. (2003). "Sustainability and Intergenerational Justice (reproduced from "Theoria" 1997)." Pp. 487-499 in Environmental Ethics, edited by A. Light and H. Rolston. Oxford, UK.: Blackwell Publishers Ltd.

Barry, J. (2007). "Towards a Model of Green Political Economy: From Ecological Modernisation to Economic Security." Green Economics 1:446-464.

Bell, M. M. (2009). An Invitation to Environmental Sociology. California, USA: Pine Forage Press.

Boyden, S. (2001). "Nature, Society, History and Social Change." Innovation: The European Journal of Social Sciences 14:103-116.

Castro, C. J. (2004). "Sustainable Development." Organization \& Environment 17:195-225.

Cato, M. S. (2009). Green Economics. London: Earthscan. 
Clifton, D. (2009). "Security and a Sustainable World." Journal of Sustainable Development 2:3-17.

Common, M. and S. Stagl. (2005). Ecological Economics. Cambridge: University Press.

Daly, H. E. (1990). "Toward Some Operational Principles of Sustainable Development." Ecological Economics 2:1-6.

-. (1996). Beyond Growth: The Economics of Sustainable Development. Boston: Beacon Press.

Daly, H. and J. Farley. (2004). Ecological Economics: Principles and Applications. Washington: Island Press.

Dauvergne, P. (2008). The Shadows of Consumption. Cambridge, MA, USA: MIT Press.

Diesendorf, M. (1997). "Principles of Ecological Sustainability." Pp. 64-97 in Human Ecology, Human Economy, edited by M. Diesendorf and C. Hamilton. Sydney: Allen \& Unwin.

Dobson, A. (1996). "Environmental Sustainabilities: An Analysis and a Typology." Environmental Politics 5:401-428.

Douthwaite, R. (1999). The Growth Illusion. Dublin: The Lilliput Press.

Dovers, S. R. (2005). Environment and Sustainability Policy: Creation, Implementation, Evaluation. Leichhardt, NSW: The Federation Press.

ECC. (2000). "The Earth Charter." Earth Charter Commission.

Ehrlich, P. R. and A. H. Ehrlich. (2008). "The Dominant Animal." Washington DC: Island Press.

Engel, J. R. (2004). "A Covenant Model of Global Ethics." Worldviews: Environment Culture Religion 8:29-46.

Farley, J., J. D. Erickson, and H. Daly. (2005). Ecological Economics: A Workbook for Problem Based Learning. Washington DC: Island Press.

Footprint Network. (2008). "Ecological Footprint." vol. 2008: Footprint Network.

Fox, W. (1995). Toward a Transpersonal Ecology. New York: State University of New York Press.

-. (2003). "Deep Ecology: A New Philosophy of Our Time (reproduced from "The Ecologist" 1984)." Pp. 252-261 in Environmental Ethics, edited by A. Light and H. Rolston. Oxford, UK.: Blackwell Publishers Ltd.

Friedman, B. M. (2006). The Moral Consequences of Economic Growth. New York: Vintage Books.

Gare, A. (2000). "The Postmodernism of Deep Ecology, the Deep Ecology of Postmodernism, and Grand Narratives." in Beneath the Surface: Critical Essays in the Philosophy of Deep Ecology, edited by E. Katz, A. Light, and S. Rothenberg. Cambridge, Massachusetts: MIT Press.

Gladwin, T. N., J. J. Kennelly, and T-S Krause. (1995). "Shifting Paradigms for Sustainable Development: Implications for Management Theory and Research." Academy of Management Review 20:874-907.

Goodland, R. (1995). "The Concept of Environmental Sustainability." Annual Review of Ecology \& Systematics 26:1-24.

Gould, K. A. and T. L. Lewis. (2009). "The Paradoxes of Sustainable Development." Pp. 269-289 in Twenty Lessons in Environmental Sociology, edited by K. A. Gould and T. L. Lewis. New York: Oxford University Press.

Gould, K. A., D. N. Pellow, and A. Schnaiberg. (2008). The Treadmill of Production. Boulder, Colorado USA: Paradigm Publishers.

Hamilton, C. (2007). Scorcher: The Dirty Politics of Climate Change. Melbourne: Black Inc.

Handmer, J. W. and S. R. Dovers. (1996). "A Typology of Resilience: Rethinking Institutions for Sustainable Development." Industrial and Environmental Crisis Quarterly 9:482-511.

Hargrove, E. C. (2003). "Weak Anthropocentric Intrinsic Value (reproduced from "The Monist", 1992)." Pp. 175-190 in Environmental Ethics, edited by A. Light and H. Rolston. Oxford, UK.: Blackwell Publishers Ltd.

Hart, S. L. (2007). Capitalism at the Crossroads. New Jersey: Pearson Education.

Hediger, W. (1999). "Reconciling "Weak" and "Strong" Sustainability." International Journal of Social Economics 26:1120-1143.

Hoggan, J. (2009). Climate Cover-Up. Vancouver: Greystone Books.

Holbrook, D. (2009). "The Consequentialist Side of Environmental Ethics (reprint of Daniel Holbrook, 'Consequentialist Side of Environmental Ethics', in Environmental Values, 6, 1997, pp. 87-96)." in The Environmental Responsibility Reader, edited by M. Reynolds, C. Blackmore, and M. J. Smith. London: Zed Books.

Holdren, J. P., G. C. Daily, and P. R. Ehrlich. (1995). "The Meaning of Sustainability: Biogeophysical Aspects." United Nations University and The World Bank, Washington DC.

Holland, A. (1997). "Substitutability." Pp. 119-134 in Valuing Nature? Ethics, Economics and the Environment, edited by J. Foster. London: Routledge. 
Holling, C.S. (1996). "Engineering Resilience versus Ecological Resilience." Pp. 31-44 in Engineering Within Ecological Constraints, edited by P. C. Schulze. Washington, D.C.: National Academy Press.

Ikeme, J. (2003). "Equity, environmental justice and sustainability: incomplete approaches in climate change politics." Global Environmental Change 13:195-206.

Jackson, T. (2009). Prosperity Without Growth. London: Earthscan.

Kallio, T. J., P. Nordberg, and A. Ahonen. (2007). "Rationalizing Sustainable Development - A Critical Treatise." Sustainable Development 15:41-51.

Kempf, H. (2008). How the Rich are Destroying the Earth. Devon, UK: Green Books.

Laferriere, E. and P. J. Stoett. (2006). "International EcoPolitical Theory: Critical Approaches." Vancouver: UBC Press.

Leopold, A. (2003). "The Land Ethic (reproduced from "A Sand Country Almanac: And Sketches Here and There", 1949)." Pp. 38-46 in Environmental Ethics, edited by A. Light and H. Rolston. Oxford, UK.: Blackwell Publishers Ltd.

Light, A. (2000). "Callicott and Naess on Pluralism." in Beneath the Surface: Critical Essays in the Philosophy of Deep Ecology, edited by E. Katz, A. Light, and S. Rothenberg. Cambridge, Massachusetts: MIT Press.

Light, A. and H. Rolston. (2003). "Introduction: Ethics and Environmental Ethics." Pp. 1-11 in Environmental Ethics. Oxford, UK.: Blackwell Publishers Ltd.

Madore, D. (2006). "Nietzsche's Conception of Life as Overcoming." in International EcoPolitical Theory: Critical Approaches, edited by E. Laferriere and P. J. Stoett. Vancouver: UBC Press.

McGregor, A. (2004). "Sustainable Development and 'Warm Fuzzy Feelings': Discourse and Nature Within Australian Environmental Imaginaries." Geoforum 35:593-606.

McLaughlin, A. (1995). "The Heart of Deep Ecology." in Deep Ecology for the 21st Century, edited by G. Sessions. Boston, USA: Shambhala Publications Inc.

McManus, P. (1996). "Contested Terrains: Politics, Stories and Discourses of Sustainability." Environmental Politics 5:48-73.

Minteer, B. A. (2009). "Nature in Common." Philadelphia: Temple University Press.

Naess, A. (1988). "Sustainable Development and the Deep Long-Range Ecology Movement." The Trumpeter 5:138-142.

-. (1989). Ecology, Community and Lifestyle. Cambridge: Cambridge University Press.

- (2003). "The Deep Ecological Movement: Some Philosophical Aspects (reproduced from "Philosophical Inquiry" 1986)." Pp. 262-274 in Environmental Ethics, edited by A. Light and H. Rolston. Oxford, UK.: Blackwell Publishers Ltd.

-. (2005). "The Basics of Deep Ecology." The Trumpeter 21:61-71.

Norton, B. G. (2003). "Environmental Ethics and Weak Anthropocentrism (reproduced from "Environmental Ethics", 1984)." Pp. 163-174 in Environmental Ethics, edited by A. Light and H. Rolston. Oxford, UK.: Blackwell Publishers Ltd.

nrg4SD. (2002). "nrg4SD: Information Package for the Network." Network of Regional Governments for Sustainable Development.

Nurse, K. (2006). "Culture as the Fourth Pillar of Sustainable Development." UN Food and Agriculture Organisation - Sustainable Agriculture and Rural Development Initative.

O'Neill, J., A. Holland, and A. Light. (2008). Environmental Values. Abingdon, UK: Routledge.

Palmer, C. (2003). "An Overview of Environmental Ethics." Pp. 15-37 in Environmental Ethics, edited by A. Light and H. Rolston. Oxford, UK.: Blackwell Publishers Ltd.

Pearse, G. (2007). High \& Dry. Camberwell, Victoria: Penguin Group (Australia).

Peattie, K. (2001). "Towards Sustainability: The Third Age of Green Marketing." Marketing Review 2.

Porritt, J. (2005). Capitalism As If The World Matters. London: Earthscan.

Princen, T. (2005). The Logic of Sufficiency. Cambridge MA, USA: MIT Press.

Robinson, J. (2004). "Squaring the Circle? Some Thoughts on the Idea of Sustainable Development." Ecological Economics 48:369-384.

Rodman, J. (1995). "Four Forms of Ecological Consciousness Reconsidered." in Deep Ecology for the 21st Century, edited by G. Sessions. Boston, USA: Shambhala Publications Inc.

Schlosberg, D. (2007). Defining Environmental Justice. Oxford: Oxford University Press.

Speth, J. G. (2005). Red Sky at Morning. New Haven, USA: Yale University Press. 
-. (2008). The Bridge at the End of the World. London: Yale University Press.

Taylor, P. (1989). Respect for Nature. Princeton: Princeton University Press.

UN. (1992a). "Agenda 21." UN Department of Economic and Social Affairs - Division for Sustainable Development.

—. (1992b). "Rio Declaration on Environment and Development."

Wackernagel, M. and W. E. Rees. (1997). "Perceptual and Structural Barriers to Investing in Natural Capital: Economics From an Ecological Footprint Perspective." Ecological Economics 20:3-24.

Walker, B. and D. Salt. (2006). Resilience Thinking: Sustaining Ecosystems and People in a Changing World. Washington DC: Island Press.

WBCSD. (2008). "The World Business Council for Sustainable Development - web site." vol. 2008.

WCED. (1987). Our Common Future: World Commission on Environment and Development. Oxford: Oxford University Press.

Williams, C. C. and A. C. Millington. (2004). "The Diverse and Contested Meanings of Sustainable Development." Geographical Journal 170:99-104.

Wissenburg, M. (2001). "Dehierarachization and Sustainable Development in Liberal and Non-Liberal Societies." Global Environmental Politics 1:95.

\section{Endnotes}

Note 1. A full list of reference sources used for construction of the SWT is available from this paper's author.

Note 2. Detailed analysis documents for each of the SWT Dimensions are available from this paper's author.

Note 3. It is noted that the use of terms such as equity, environmental justice, distributive justice, procedural justice and so on are used inconsistently in the literature (Ikeme 2003) with justice seen mostly as a matter of fair and equitable distribution in society (Barry 2003; Ikeme 2003). In the sustainability literature however, broader dimensions of justice including distribution, recognition, capabilities, and participation, are evident whether talked of explicitly or wrapped up in general distributional based narratives (for a discussion on this point, see Schlosberg (2007)). 
Figure 1. Sustainable World Typology (SWT)

1. Dimensions: Sustainable World (SW) Dimensions represented in the SWT are:

\begin{tabular}{|l|c|}
\hline $\begin{array}{l}\text { SWT } \\
\text { Reference }\end{array}$ & SWT Dimension description \\
\hline 1. & Primary goal of a Sustainable World \\
\hline \multicolumn{1}{|l|}{1.1.} & Primary Goal \\
\hline \multicolumn{1}{|l|}{1.2.} & Primary Goal area of focus \\
\hline $\mathbf{2 .}$ & Space and time \\
\hline $\mathbf{3 .}$ & Satisfaction of interests \\
\hline 3.1. & Interests: Scope \\
\hline $3.2(\mathrm{a})$. & Interests: Mechanism (human) \\
\hline $3.2(\mathrm{~b})$. & Interests: Mechanism (non-human) \\
\hline $3.3(\mathrm{a})$. & Interests: Population (human) \\
\hline $3.3(\mathrm{~b})$. & Interests: Population (non-human) \\
\hline $\mathbf{4 .}$ & Responsibility \\
\hline 4.1. & Cause \\
\hline 4.2. & Remedy \\
\hline
\end{tabular}

\begin{tabular}{|c|c|}
\hline $\begin{array}{l}\text { SWT } \\
\text { Reference }\end{array}$ & SWT Dimension description \\
\hline 5. & General principles and concepts \\
\hline 5.1. & $\begin{array}{c}\text { Modelling a SW - the 3-Element } \\
\text { Model }\end{array}$ \\
\hline 5.2. & Justice \\
\hline 5.3. & Human Interests - Resources \\
\hline 5.4. & Risk and Precaution \\
\hline 5.5. & Growth and Development \\
\hline 5.6. & Diversity \\
\hline 5.6 .1$. & Biodiversity \\
\hline 5.6 .2$. & Cultural diversity \\
\hline 5.7. & Security \\
\hline
\end{tabular}

2. Key to numeric codes

\begin{tabular}{|l|l|}
\hline Code & Description \\
\hline \hline (1 & SW Perspectives that best reflect the current dominant human behaviour. \\
\hline 2 & SW Perspectives that reflect of the current dominant approach to a SW. \\
\hline
\end{tabular}

3. The Sustainable World Typology

1. Primary goal of a Sustainable World: What is the primary goal of a Sustainable World - what is it that is to be sustained above all else?

\begin{tabular}{|ll|l|l}
\hline $\begin{array}{l}\text { 1.1. Primary } \\
\text { Goal }\end{array}$ & $\begin{array}{l}\text { Definitional: The primary goal of a Sustainable World is the Flourishing of life on Earth over an } \\
\text { indefinite time frame. }\end{array}$
\end{tabular}

\begin{tabular}{|c|c|c|}
\hline \multirow[t]{3}{*}{$\begin{array}{ll}1.2 . & \text { Primary } \\
\text { Goal area of } \\
\text { focus }\end{array}$} & $\begin{array}{l}\text { Reformist } \\
\text { orientation }\end{array}$ & $\begin{array}{l}2 \text { Weak anthropocentrism } \\
\text { The focus of what is to be sustained is the flourishing of human life through the } \\
\text { satisfaction of human Fulfilment Interests }{ }^{\# 1} \text { based on Considered Human } \\
\text { Preferences } \# 2 \text {. } \\
\text { The non-human world is only (or mostly) of instrumental value to humans in } \\
\text { meeting Considered Human Preferences. }\end{array}$ \\
\hline & $\begin{array}{l}\text { Transformational } \\
\text { orientation }\end{array}$ & $\begin{array}{l}\text { Ecocentrism } \\
\text { The focus of what is to be sustained is the flourishing of human and non-human } \\
\text { life through the satisfaction of Fulfilment Interests. } \\
\text { Both human and non-human interests given consideration - humans interests do } \\
\text { not take automatic preference. }\end{array}$ \\
\hline & $\begin{array}{l}\text { Inconsistent with } \\
\text { both Reformist and } \\
\text { Transformational } \\
\text { approaches }\end{array}$ & $\begin{array}{l}\text { (1 Strong anthropocentrism } \\
\text { The satisfaction of human interests, based on Felt Human Preferences }{ }^{\# 3} \text {, } \\
\text { dominates. }\end{array}$ \\
\hline
\end{tabular}

Notes:

\#1: Fulfilment Interests: are those things that are conducive to the flourishing of something (a person, a society, an animal, a plant, an ecosystem, etc.).

These are high-order things which in the human context might include physical health, a sound mind, a sense of meaning and purpose in life and so on.

Fulfilment interests have some common characteristics across any one species (it is in the interests for all humans to be of good health and sound mind) and in some respects, across species boundaries (physical health is just as relevant for a human as it is for an ape or an elephant).

But there are also clear species specific fulfilment interests (a healthy cheetah is a fast cheetah, which need not be the case for a human) and at least within the human domain, there are individual differences as to how a flourishing life might be lived.

\#2: Considered Human Preferences: are "any desire or need that a human individual would express after careful deliberation, including a judgment that the desire or need is consistent with a rationally adopted world view" (Norton 2003, p. 164). In the sustainable world context, these are preferences consistent with a rationally adopted sustainable world view.

\#3: Felt Human Preferences: are "any desire or need of a human individual that can at least temporarily be sated by some specifiable experience of that individual" (Norton 2003, p. 164) 
2. Space and time: What spatial and temporal issues are relevant to the concept of a Sustainable World? Definitional: A Sustainable World is ultimately concerned with humans living sustainably at the global level over an indefinite time frame.

3. Satisfaction of interests: If a SW has to do with the flourishing of life through the satisfaction of interests:

Which needs (human and non-human) are to be met, and to what extent are they to be met, to satisfy these interests? (the Scope question).

How are these interests to be satisfied? (the Mechanism question).

For how many are these interests to be satisfied? (the Population question).

\begin{tabular}{|c|c|c|}
\hline \multirow[t]{3}{*}{$\begin{array}{l}\text { 3.1. Interests: } \\
\text { Scope }\end{array}$} & $\begin{array}{l}\text { Reformist } \\
\text { orientation }\end{array}$ & $\begin{array}{l}2 \text { Justice in meeting human needs and wants } \\
\text { Justice in meeting human Fulfilment Needs }{ }^{\# 4} \text {, then justice in meeting human } \\
\text { wants }^{\# 5} \text {. } \\
\text { Non-human species interest satisfaction based mostly, but not always, on the } \\
\text { usefulness of non-human species in satisfying human interests. }\end{array}$ \\
\hline & $\begin{array}{l}\text { Transformational } \\
\text { orientation }\end{array}$ & $\begin{array}{l}\text { Justice in meeting needs for all life } \\
\text { First, justice in meeting Fulfilment Needs for humans and non-human species. } \\
\text { Then when achieved, justice in meeting human wants. }\end{array}$ \\
\hline & $\begin{array}{l}\text { Inconsistent with } \\
\text { both Reformist and } \\
\text { Transformational } \\
\text { approaches }\end{array}$ & $\begin{array}{l}\text { (1 Unjust human need and want satisfaction } \\
\text { Human Felt Preferences dominate, and/or } \\
\text { Only vital human needs met, and/or } \\
\text { Unjust human interest satisfaction. }\end{array}$ \\
\hline
\end{tabular}

Notes:

\#4: Fulfilment needs: are those things that must be satisfied in order for fulfilment interests to be met - wholesome and adequate food for physical health, strong social relationships and family bonds for psychological health, and so on.

\#5: Human wants: are those things that go beyond fulfilment needs and are 'like to haves' but are not conditional for a flourishing life to be lived. I might like to trek through the Himalayas, but I can still live a flourishing life without it. Wants are mostly seen as applicable only to humans and although not dismissing the possibility that wants might also apply to non-human species, the limitation to humans is followed in this SWT.

\begin{tabular}{|c|c|c|}
\hline \multirow[t]{3}{*}{$\begin{array}{l}\text { 3.2(a). } \\
\text { Interests: } \\
\text { Mechanism } \\
\text { (human) }\end{array}$} & $\begin{array}{l}\text { Reformist } \\
\text { orientation }\end{array}$ & $\begin{array}{l}2 \text { Green and equitable consumerism } \\
\text { Focus on consumerism with goods and services produced and consumed in } \\
\text { environmentally responsible and socially just (green-and-just) ways. } \\
\text { Consumption that increases GDP for all of humanity is a fundamental social } \\
\text { good. }\end{array}$ \\
\hline & $\begin{array}{l}\text { Transformational } \\
\text { orientation }\end{array}$ & $\begin{array}{l}\text { Sufficiency and life experiences } \\
\text { Focus on non-material life experiences. } \\
\text { Consumption of goods and services based on sufficiency criteria. } \\
\text { Increased consumption needs of the poor are important and achieved through } \\
\text { redistribution not more growth. } \\
\text { Human wellbeing from a close connection to Nature. }\end{array}$ \\
\hline & $\begin{array}{l}\text { Inconsistent with } \\
\text { both Reformist and } \\
\text { Transformational } \\
\text { approaches }\end{array}$ & $\begin{array}{l}\text { (1 Unconstrained materialism } \\
\text { Consumption of goods and services with little regard for broad-scale and } \\
\text { long-term environmental or social consequences. }\end{array}$ \\
\hline
\end{tabular}




\begin{tabular}{|c|c|c|}
\hline \multirow[t]{3}{*}{$\begin{array}{l}3.2(\mathrm{~b}) . \\
\text { Interests: } \\
\text { Mechanism } \\
\text { (non-human) }\end{array}$} & $\begin{array}{l}\text { Reformist } \\
\text { orientation }\end{array}$ & $\begin{array}{l}2 \text { Constrained to human parameters - Weak Anthropocentrism orientation } \\
\text { Non-human life managed by humans mostly as natural resources for satisfaction } \\
\text { of human Considered Preferences. } \\
\text { Supportive of technology-focused agricultural practices, including the use of } \\
\text { GMOs and other intensive technology based crop and animal production } \\
\text { practices, if done in ways consistent with the 'green and just' Reformist criteria. }\end{array}$ \\
\hline & $\begin{array}{l}\text { Transformational } \\
\text { orientation }\end{array}$ & $\begin{array}{l}\text { Unconstrained flourishing - Ecocentrism orientation } \\
\text { Humans manage themselves rather than managing Nature, with a guiding } \\
\text { principle of minimal interference with Nature to allow it to evolve and flourish in } \\
\text { its own way. } \\
\text { Preference for organic agricultural practices, and an aversion to GMO technology } \\
\text { and other intensive technology based crop and animal production practices. }\end{array}$ \\
\hline & $\begin{array}{l}\text { Inconsistent with } \\
\text { both Reformist and } \\
\text { Transformational } \\
\text { approaches }\end{array}$ & $\begin{array}{l}\text { (1 Strong anthropocentrism orientation } \\
\text { Interests of non-human life are only relevant to the extent to which their } \\
\text { satisfaction contributes to the meeting of human Felt Preferences. } \\
\text { Use of technology focused agricultural practices including GMOs and other } \\
\text { intensive technology based crop and animal production practices even if negative } \\
\text { ecological and social consequences arise. }\end{array}$ \\
\hline
\end{tabular}

\begin{tabular}{|c|c|c|}
\hline \multirow[t]{3}{*}{$\begin{array}{l}.3(\mathrm{a}) . \\
\text { Interests: } \\
\text { Population } \\
\text { (human) }\end{array}$} & $\begin{array}{l}\text { Reformist } \\
\text { orientation }\end{array}$ & $\begin{array}{l}\text { (1 } \$ 6 \text { Manage a SW to Population } \\
\text { Population settles to a 'natural limit'. } \\
\text { Reduce very high rates of growth in some (mostly developing) countries. } \\
\text { Prevent reductions in some (mostly developed) countries. } \\
\text { Orientation to maximizing human population that can be sustained within SW } \\
\text { criteria. }\end{array}$ \\
\hline & $\begin{array}{l}\text { Transformational } \\
\text { orientation }\end{array}$ & $\begin{array}{l}\text { Manage Population to a SW } \\
\text { Current human population seen as too high and unsustainable, and is an issue for } \\
\text { all countries to address. } \\
\text { Long term reduction strategy required through collective non-coercive and } \\
\text { non-discriminatory choice. } \\
\text { Reduction will benefit both humans and other species. }\end{array}$ \\
\hline & $\begin{array}{l}\text { Inconsistent with } \\
\text { both Reformist and } \\
\text { Transformational } \\
\text { approaches }\end{array}$ & $\begin{array}{l}\text { (16 Growth beyond capacity } \\
\text { Population-impact mix that exceeds the Earth's ecosystem capacity and/or } \\
\text { exceeds society's economic capacity to meet Fulfilment Needs for all. } \\
\text { Indefinite population growth. } \\
\text { Coercive or discriminatory methods to limit growth. }\end{array}$ \\
\hline
\end{tabular}

Notes:

\#6: Current human behaviour shows signs of both the Reformist view through a current approach oriented towards stabilising global population numbers, plus being inconsistent with any SW formulation through the current unsustainable population-impact mix.

\begin{tabular}{|c|c|c|}
\hline \multirow[t]{3}{*}{$\begin{array}{l}\text { 3.3(b). } \\
\text { Interests: } \\
\text { Population } \\
\text { (non-human) }\end{array}$} & $\begin{array}{l}\text { Reformist } \\
\text { orientation }\end{array}$ & $\begin{array}{l}2 \text { Constrained to human interests - Weak Anthropocentrism } \\
\text { Non-human species diversity and population numbers mostly constrained to the } \\
\text { extent needed to satisfy human instrumental objectives and self-interest pursuit. } \\
\text { Consistent with a weak anthropocentric world view including maintaining critical } \\
\text { levels of natural capital }\left(\mathrm{K}_{\mathrm{N}}\right) \text { and satisfying Human Considered Preferences. }\end{array}$ \\
\hline & $\begin{array}{l}\text { Transformational } \\
\text { orientation }\end{array}$ & $\begin{array}{l}\text { Flourishing - Ecocentrism } \\
\text { Non-human species flourish in their own right independently of human } \\
\text { instrumental purposes or self-interest pursuit, characterised by abundance in } \\
\text { biodiversity and in species population sizes. } \\
\text { Requires ceasing of human caused extinctions and significant increases in } \\
\text { population numbers for most species. }\end{array}$ \\
\hline & $\begin{array}{l}\text { Inconsistent with } \\
\text { both Reformist and } \\
\text { Transformational } \\
\text { approaches }\end{array}$ & $\begin{array}{l}\text { (1 Critical Natural Capital and Considered Preference erosion } \\
\text { Loss of species and species populations so as to erode critical levels of } K_{N} \text { and } \\
\text { erode the satisfaction of Considered Human Preferences in ways consistent with } \\
\text { other SW criteria. }\end{array}$ \\
\hline
\end{tabular}




\begin{tabular}{|c|c|c|}
\hline \multicolumn{3}{|c|}{$\begin{array}{l}\text { 4. Responsibility: Who is responsible for the current unsustainable state and trajectory of the world, and who is responsible } \\
\text { for remedying it? }\end{array}$} \\
\hline \multirow[t]{4}{*}{ 4.1. Cause } & \multicolumn{2}{|c|}{$\begin{array}{l}\text { Humans: } \\
\text { Current SW problems are solely human caused, that is, they are human society created problems. } \\
\text { Within this human context, various social actors are claimed to have contributed in different ways that can } \\
\text { be considered within the Reformist and Transformational framework. }\end{array}$} \\
\hline & $\begin{array}{l}\text { Reformist } \\
\text { orientation }\end{array}$ & $\begin{array}{l}\text { (1) Wealth and Poverty, North and South } \\
\text { Production and consumption patterns of the wealthy - especially in the North, } \\
\text { poverty in the South, and a lack of development in the South, are key causes of } \\
\text { ecological harm and SW problems generally. }\end{array}$ \\
\hline & $\begin{array}{l}\text { Transformational } \\
\text { orientation }\end{array}$ & $\begin{array}{l}\text { Wealth and North } \\
\text { Production and consumption in the North, exploitation of the South by the North } \\
\text { by both business and government, and efforts by the South to replicate Northern } \\
\text { consumptive lifestyles, are the dominant causes of SW problems. }\end{array}$ \\
\hline & $\begin{array}{l}\text { Inconsistent with } \\
\text { both Reformist and } \\
\text { Transformational } \\
\text { approaches }\end{array}$ & $\begin{array}{l}\text { ( }{ }^{\# 7} \text { Responsibility Denial } \\
\text { A general failure of social actors (nations, governments, business, society } \\
\text { generally etc), especially by those having greatest influence over impacts, to } \\
\text { acknowledge their contribution to SW problems. }\end{array}$ \\
\hline
\end{tabular}

Notes:

\#7: Current human behaviour shows signs of Reformist acknowledgement of the cause of current SW problems and denial of responsibility, depending on the issues being considered and the implications resulting from responsibility acknowledgement.

\begin{tabular}{|c|c|c|}
\hline \multirow[t]{4}{*}{ 4.2. Remedy } & \multicolumn{2}{|c|}{$\begin{array}{l}\text { Humans: } \\
\text { Humans are the only entity able to think about SW issues and to do something about them. } \\
\text { Within this human context, various social actors are claimed to have different remedial roles to play that } \\
\text { can be considered within the Reformist and Transformational framework. }\end{array}$} \\
\hline & $\begin{array}{l}\text { Reformist } \\
\text { orientation }\end{array}$ & $\begin{array}{l}2 \text { North and business led global green-and-just growth } \\
\text { North to make its production and consumption more green-and-just and help the } \\
\text { South develop sustainably through institutional reform and application of capital } \\
\text { and technology. } \\
\text { South to embrace Northern economic ideals in green-and-just ways consistent } \\
\text { with a Reformist SW view. } \\
\text { Business has a key role in promoting global growth in partnership with } \\
\text { government, based on a Reformist SW view. } \\
\text { Individual responsibility to make green-and-just consumer choices. }\end{array}$ \\
\hline & $\begin{array}{l}\text { Transformational } \\
\text { orientation }\end{array}$ & $\begin{array}{l}\text { North restraint and sufficiency, South self determinism } \\
\text { North to bring its production and consumption within fair Earth-share limits and } \\
\text { to stop exploiting the South. } \\
\text { South to find its own way of living sustainably and without replicating the } \\
\text { unsustainable ways of the North. } \\
\text { Business size and power constrained by government with a preference for the } \\
\text { small and local. } \\
\text { Government policies to limit scale of resource consumption and of distributional } \\
\text { inequality, and support wellbeing within these constraints based on } \\
\text { Transformational principles. } \\
\text { Individual responsibility to adopt sufficiency lifestyles. }\end{array}$ \\
\hline & $\begin{array}{l}\text { Inconsistent with } \\
\text { both Reformist and } \\
\text { Transformational } \\
\text { approaches }\end{array}$ & $\begin{array}{l}\text { (1 Responsibility Avoidance } \\
\text { A general failure of social actors (nations, governments, business, society } \\
\text { generally etc), especially by those having greatest ability to bring about change, } \\
\text { to take needed action to progress a SW outcome. }\end{array}$ \\
\hline
\end{tabular}




\begin{tabular}{|c|c|c|c|}
\hline \multicolumn{4}{|c|}{ 5. General principles and concepts } \\
\hline \multirow[t]{5}{*}{$\begin{array}{l}\text { 5.1. Modelling } \\
\text { a SW - the } \\
\text { 3-Element } \\
\text { Model }\end{array}$} & $\begin{array}{l}\text { Reformist } \\
\text { orientation }\end{array}$ & \multicolumn{2}{|c|}{$\begin{array}{l}2 \text { Interlocking circles / 3-legged-stool/3-pillars } \\
\text { Ecological, Social and Economic as separate but equally important and } \\
\text { interrelated aspects of a SW. } \\
\text { No absolute limits. } \\
\text { Allows trade-offs consistent with Weak Sustainability (see SWT item 5.3). }\end{array}$} \\
\hline & \multirow{3}{*}{$\begin{array}{l}\text { Transformational } \\
\text { orientation } \\
\text { (increasingly } \\
\text { moving downwards } \\
\text { from 'clear system } \\
\text { boundaries' } \\
\text { 'single to } \\
\text { activity field') }\end{array}$} & \multirow{3}{*}{$\begin{array}{l}\text { Concentric circles } \\
\text { Economy dependent on } \\
\text { and constrained by } \\
\text { Social, which is } \\
\text { dependent on and } \\
\text { constrained } \\
\text { Ecological. }\end{array}$} & $\begin{array}{l}\text { Clear system boundaries } \\
\text { Boundaries of the } 3 \text { systems are clear and easily } \\
\text { definable. }\end{array}$ \\
\hline & & & $\begin{array}{l}\text { Diffuse and permeable boundaries } \\
\text { Boundaries of the } 3 \text { systems are diffuse and permeable. }\end{array}$ \\
\hline & & & $\begin{array}{l}\text { Single human 'activity and wellbeing' field within } \\
\text { surrounding Ecological } \\
\text { Human wellbeing focus with no Economic distinction. } \\
\text { Human 'activity and wellbeing' field boundary diffuse } \\
\text { and permeable. }\end{array}$ \\
\hline & $\begin{array}{l}\text { Inconsistent with } \\
\text { both Reformist and } \\
\text { Transformational } \\
\text { approaches }\end{array}$ & \multicolumn{2}{|c|}{$\begin{array}{l}\text { D }^{\# 8} \text { Ecological and social subservience } \\
\text { Ecological not at least on equal terms with Social and Economic. } \\
\text { Social not on at least equal terms with Economic. }\end{array}$} \\
\hline
\end{tabular}

Notes:

\#8: The current human behaviour notation is from an economic dominance perspective where Social and Ecological are subservient to Economic.

\begin{tabular}{|c|c|c|}
\hline \multirow[t]{4}{*}{ 5.2. Justice } & \multicolumn{2}{|c|}{$\begin{array}{l}\text { For all formulations of a SW } \\
\text { Achieving both Intra-generational (IntraG) and Inter-generational (InterG) justice is a necessary condition } \\
\text { for a SW. } \\
\text { Ultimately it is justice in outcomes that matter (i.e., consequentialist based) that is, any process approach } \\
\text { to justice (i.e. deontological based) is only as good as the SW outcomes it produces. } \\
\text { Justice is considered in multi-dimensional terms including distribution (i.e. equity), recognition, } \\
\text { capabilities, and participation. }\end{array}$} \\
\hline & $\begin{array}{l}\text { Reformist } \\
\text { orientation }\end{array}$ & $\begin{array}{l}\text { Human focused and growth based } \\
\text { IntraG and InterG justice are relevant to humans only. } \\
\text { Overcoming poverty and achieving a more equitable distribution of wealth } \\
\text { requires continued economic growth with the benefits of growth equitably shared. } \\
\text { InterG justice requires the passing on to future generations of an undiminished } \\
\text { aggregate resource capital base (i.e., a weak sustainability approach - see item } \\
\text { 5.3). }\end{array}$ \\
\hline & $\begin{array}{l}\text { Transformational } \\
\text { orientation }\end{array}$ & $\begin{array}{l}\text { Humans and Nature focused and redistribution based } \\
\text { IntraG and InterG justice are relevant to humans and to human acts towards } \\
\text { Nature. } \\
\text { Human resource consumption based on an equal 'fair-Earth share' entitlement } \\
\text { through redistribution of wealth and resource use, especially from the North to } \\
\text { the South and from humans to Nature, not through more economic growth. } \\
\text { InterG justice requires the passing on to future generations of independently } \\
\text { undiminished natural }\left(\mathrm{K}_{\mathrm{N}}\right) \text { and human made }\left(\mathrm{K}_{\mathrm{HM}}\right) \text { capital bases (i.e., a strong } \\
\text { sustainability approach - see item 5.3) based on ecocentric principles. }\end{array}$ \\
\hline & $\begin{array}{l}\text { Inconsistent with } \\
\text { both Reformist and } \\
\text { Transformational } \\
\text { approaches }\end{array}$ & $\begin{array}{l}\text { (1) IntraG and/or InterG injustice } \\
\text { Members of the current generation not having basic needs physically met and/or } \\
\text { not having the opportunity to lead flourishing lives. } \\
\text { Future generations being unable to meet their basic needs or otherwise lead } \\
\text { flourishing lives as a consequence of harmful actions taken by the current } \\
\text { generation. }\end{array}$ \\
\hline
\end{tabular}




\begin{tabular}{|c|c|c|}
\hline $\begin{array}{l}\text { 5.3. Human } \\
\text { Interests - } \\
\text { Resources }\end{array}$ & $\begin{array}{l}\text { Reformist } \\
\text { orientation }\end{array}$ & $\begin{array}{l}2 \text { Weak Sustainability (WS) } \\
\text { Sustainability of human interests satisfaction requires that the aggregate value of } \\
\text { natural }\left(\mathrm{K}_{\mathrm{N}}\right) \text { and human forms }\left(\mathrm{K}_{\mathrm{HF}}\right) \text { of capital is sustained. } \\
\text { Capital types are substitutable beyond minimum critical values. }\end{array}$ \\
\hline & $\begin{array}{l}\text { Both Reformist and } \\
\text { Transformational } \\
\text { features }\end{array}$ & $\begin{array}{l}\text { Strong Sustainability (SS) - Weak Anthropocentrism orientation } \\
\text { Sustainability of human interests satisfaction requires } \mathrm{K}_{\mathrm{N}} \text { and } \mathrm{K}_{\mathrm{HF}} \text { to be } \\
\text { maintained separately. } \\
\mathrm{K}_{\mathrm{N}} \text { and } \mathrm{K}_{\mathrm{HF}} \text { are mostly complements and only marginally substitutable. }\end{array}$ \\
\hline & $\begin{array}{l}\text { Transformational } \\
\text { orientation }\end{array}$ & $\begin{array}{l}\text { Strong Sustainability (SS) - Ecocentrism orientation } \\
\text { SS reconstructed to incorporate ecocentric principles. } \\
\mathrm{K}_{\mathrm{N}} \text { as Nature rather than as merely aspects of Nature useful to humans. } \\
\mathrm{K}_{\mathrm{HF}} \text { incorporates values beyond it being a form of capital. }\end{array}$ \\
\hline & $\begin{array}{l}\text { Inconsistent with } \\
\text { both Reformist and } \\
\text { Transformational } \\
\text { approaches }\end{array}$ & $\begin{array}{l}\text { (1) Aggregate capital depletion } \\
\text { The depletion of the aggregate of } K_{N} \text { and } K_{H F} \text {. } \\
\text { Very Weak Sustainability } \\
\text { The proposition that } K_{H F} \text { is perfectly and indefinitely substitutable for } K_{N} \text {. }\end{array}$ \\
\hline
\end{tabular}

\begin{tabular}{|c|c|c|}
\hline $\begin{array}{l}\text { 5.4. Risk and } \\
\text { Precaution }\end{array}$ & $\begin{array}{l}\text { Reformist } \\
\text { orientation }\end{array}$ & $\begin{array}{l}2 \text { Risk Management } \\
\text { Maximisation and optimisation of human activity. } \\
\text { Ignorance and uncertainty are acknowledged, and risks from human activity are } \\
\text { managed mostly through application of science and weaker forms of } \\
\text { Precautionary Principle (PP). } \\
\text { Risk aversion to change in social systems and institutions beyond marginal } \\
\text { change consistent with Reformism principles. }\end{array}$ \\
\hline & $\begin{array}{l}\text { Transformational } \\
\text { orientation }\end{array}$ & $\begin{array}{l}\text { Resilience Living } \\
\text { Socio-ecological Resilience Living pursued instead of human activity strategies } \\
\text { oriented to maximisation and optimisation. } \\
\text { Ignorance and uncertainty strongly recognised. } \\
\text { Stronger forms of the PP, and use of broad forms of knowledge in addition to } \\
\text { scientific, are also utilised to address risk. } \\
\text { Risk tolerant of fundamental change to social systems and institutions to see } \\
\text { primary SW goals achieved. }\end{array}$ \\
\hline & $\begin{array}{l}\text { Inconsistent with } \\
\text { both Reformist and } \\
\text { Transformational } \\
\text { approaches }\end{array}$ & $\begin{array}{l}\text { (1 Restrained risk management or Risk Indifference } \\
\text { Ignoring or attempting to factor-out issues of uncertainty and ignorance in } \\
\text { decision making processes, include a failure to utilise, in a broad way, the PP in } \\
\text { either a weak or strong form. } \\
\text { Failure to make meaningful changes, even at the margin, to social and } \\
\text { institutional systems to address SW risks arising from human activity. }\end{array}$ \\
\hline
\end{tabular}

\begin{tabular}{|c|c|c|}
\hline \multirow[t]{3}{*}{$\begin{array}{l}\text { 5.5. Growth } \\
\text { and } \\
\text { Development }\end{array}$} & $\begin{array}{l}\text { Reformist } \\
\text { orientation }\end{array}$ & $\begin{array}{l}\text { Sustainable Growth } \\
\text { Human wellbeing, including elimination of poverty and resolution of ecological } \\
\text { problems, achieved through green-and-just, unlimited, and global GDP growth } \\
\text { supported by free-trade, market based SW incentives, and a key role for the } \\
\text { business sector. } \\
\text { Technology and human ingenuity as keys to resolving problems caused by } \\
\text { growth and to overcome limits to growth }\end{array}$ \\
\hline & $\begin{array}{l}\text { Transformational } \\
\text { orientation }\end{array}$ & $\begin{array}{l}\text { Qualitative Development and Sufficiency } \\
\text { Human wellbeing progressed through green-and-just qualitative development and } \\
\text { consumptive sufficiency, achieved through a steady-state economy, } \\
\text { internationalisation not globalization, and a preference for consumption from } \\
\text { local production. } \\
\text { Continued consumptive growth not sustainable or possible, and is a cause of } \\
\text { ecological problems and of poverty. }\end{array}$ \\
\hline & $\begin{array}{l}\text { Inconsistent with } \\
\text { both Reformist and } \\
\text { Transformational } \\
\text { approaches }\end{array}$ & $\begin{array}{l}\text { D }^{\# 9} \text { Ecologically unsustainable and/or socially unjust economic growth } \\
\text { Economic growth that breaches green-and-just principles. }\end{array}$ \\
\hline
\end{tabular}

Notes:

\#9: The current dominant human behaviour also includes most features of the Reformist growth agenda. The difference is that Reformism seeks to address ecological and justice problems not being resolved under current arrangements. 


\begin{tabular}{|c|c|c|}
\hline 5.6. Diversity & $\begin{array}{l}\text { For all formulations of } \\
\text { Both biodiversity and } \mathrm{c} \\
\text { mutually supportive, and }\end{array}$ & $\begin{array}{l}\text { Wal diversity are seen under all SW Diversity Perspectives as being interdependent, } \\
\text { ressary and equally important for there to be a SW. }\end{array}$ \\
\hline \multirow[t]{3}{*}{$\begin{array}{l}5.6 .1 . \\
\text { Biodiversity }\end{array}$} & Reformist orientation & $\begin{array}{l}\text { Constrained to human (weak anthropocentric) interests } \\
\text { Biodiversity loss inevitable and acceptable but not below levels consistent with weak } \\
\text { anthropocentrism and not below either of: } \\
\text { (a) } 2 \text { Critical } \mathrm{K}_{\mathrm{N}} \text { levels for a WS approach, or } \\
\text { (b) More significant than critical } \mathrm{K}_{\mathrm{N}} \text { levels for a SS approach. } \\
\text { Consistent with mono-culture industrial agricultural practices including the } \\
\text { precautionary use of GMO technology. }\end{array}$ \\
\hline & $\begin{array}{l}\text { Transformational } \\
\text { orientation }\end{array}$ & $\begin{array}{l}\text { Flourishing } \\
\text { Biodiversity as a fundamental good and considered in ways consistent with ecocentric } \\
\text { principles. } \\
\text { Humans need to live in ways that are biodiversity enhancing. } \\
\text { Sceptical of mono-culture industrial agricultural practices and the use of GMO } \\
\text { technology. } \\
\text { Advocates a return to high diversity organic agricultural practices. }\end{array}$ \\
\hline & $\begin{array}{l}\text { Inconsistent with both } \\
\text { Reformist and } \\
\text { Transformational } \\
\text { approaches }\end{array}$ & $\begin{array}{l}\text { (1 Persistent human caused biodiversity loss } \\
\text { The persistent human caused loss of biodiversity especially where it breaches critical } \\
\mathrm{K}_{\mathrm{N}} \text { levels. }\end{array}$ \\
\hline \multirow[t]{3}{*}{$\begin{array}{l}5.6 .2 . \\
\text { Cultural } \\
\text { diversity }\end{array}$} & Reformist orientation & $\begin{array}{l}\text { (2) Constrained within dominant socio-economic system } \\
\text { Cultural diversity encouraged but exists within a dominant Reformist SW approach } \\
\text { based on globalization, free trade, GDP growth, and a green-and-just consumer } \\
\text { culture. } \\
\text { Incorporates concepts of multiculturalism, protection of indigenous rights, protection } \\
\text { of items of cultural heritage and language, and the commodification of cultural goods } \\
\text { and services. }\end{array}$ \\
\hline & $\begin{array}{l}\text { Transformational } \\
\text { orientation }\end{array}$ & $\begin{array}{l}\text { Flourishing } \\
\text { Cultural diversity as a fundamental good incorporating all aspects of human society } \\
\text { including economic systems. } \\
\text { Humans need to live in ways that are cultural diversity enhancing. }\end{array}$ \\
\hline & $\begin{array}{l}\text { Inconsistent with both } \\
\text { Reformist and } \\
\text { Transformational } \\
\text { approaches }\end{array}$ & $\begin{array}{l}\text { (1 Persistent human caused cultural diversity loss. } \\
\text { The persistent human caused loss of human cultural diversity such that it undermines } \\
\text { human Considered Preferences that are satisfied though such diversity. }\end{array}$ \\
\hline
\end{tabular}

\begin{tabular}{|c|c|c|c|}
\hline \multirow[t]{4}{*}{$\begin{array}{l}5.7 . \\
\text { Security }\end{array}$} & Reformist orientation & \multirow{2}{*}{$\begin{array}{l}\text { Human Security focus } \\
\text { Focus on broad issues of } \\
\text { Human Security and root } \\
\text { causes of insecurity. } \\
\text { Peace Dividend applied } \\
\text { to progressing human and } \\
\text { ecological wellbeing } \\
\text { objectives. }\end{array}$} & $\begin{array}{l}\text { (2) Targeted disarmament } \\
\text { General reductions in military spending. } \\
\text { Non-proliferation of, and elimination of, some types of } \\
\text { weapons, especially weapons of mass destruction (WMD). }\end{array}$ \\
\hline & $\begin{array}{l}\text { Both Reformist and } \\
\text { Transformational } \\
\text { features }\end{array}$ & & $\begin{array}{l}\text { Broad scale disarmament } \\
\text { Disarmament to minimal non-provocative defence } \\
\text { capability. } \\
\text { Stronger peace keeping capacity under international control. } \\
\text { No WMD. }\end{array}$ \\
\hline & $\begin{array}{l}\text { Transformational } \\
\text { orientation }\end{array}$ & \multicolumn{2}{|c|}{$\begin{array}{l}\text { Life Security focus } \\
\text { Focus on broad issues of security for humans and non-human species, and addressing root } \\
\text { causes of insecurity. } \\
\text { Peace Dividend applied to progressing SW objectives consistent with ecocentric } \\
\text { principles. } \\
\text { Broad scale disarmament approach. }\end{array}$} \\
\hline & 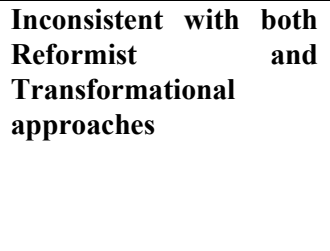 & \multicolumn{2}{|c|}{$\begin{array}{l}\text { (1 National Security focus } \\
\text { Focus on military based National Security. } \\
\text { High levels of, and/or escalating, military spending and capability. } \\
\text { Failure to progress disarmament objectives. } \\
\text { Failure to apply any Peace Dividend to human and ecological wellbeing initiatives. } \\
\text { Greening the military as a cover for militarism legitimisation. }\end{array}$} \\
\hline
\end{tabular}

